\title{
画像処理による破砕堆積物形状認識のための ビジョンシステムに関する研究*
}

$$
\text { 高 橋 } \quad \text { 弘 }^{1} \text { 菅 澤 } \text { 努 }^{2} \text { 齊 藤 } \text { 清 }^{\text {次 }}{ }^{3}
$$

\section{Study on the Vision System to Recognize the Shape of the Rock Pile by Use of Image Processing}

by Hiroshi TAKAHASHI ${ }^{1}$, Tsutomu SUGASAWA ${ }^{1}$ and Seiji SAITO ${ }^{1}$

1. Dept. of Geoscience and Technology, Graduate School of Engineering, Tohoku University, Sendai 980-8579

\begin{abstract}
Robotic excavation and loading task have been receiving considerable attention in several fields, especially in mining and construction site. In order to realize the robotic excavation by the wheel loader, the robot has to recognize the shape of the rock pile because the excavation task is planned based on the shape of the rock pile. This paper is related to the vision system to recognize the shape of the rock pile. A CCD camera was used to obtain the image of the rock pile. The image processing procedure was proposed to detect the rock pile area from the original image.
\end{abstract}

KEY WORDS : Vision System, Image Processing, Rock Pile

\section{1.は じめに}

近年，様々な分野において作業ロボットの導入が試みられ，人 員の削減，作業能率の向上および生産性向上の面で大きく貢献し ている。また危険な作業からの作業員の開放を目指して，極限作 業ロボットの開発も進められている ${ }^{1)}$ 。しかしながら, 資源開発 分野ではロボットの導入が他の分野より遅れているのが現状で ある。これは, 資源開発現場では自然界を対象とし, かつ作業環 境が常に変化するためであるといわれている2）。したがって，今 後, これらの現場に導入されるロボットには外界の状況を自ら検 知・判断し，作業を行う機能を具備することが必要である。

ところで，資源開発現場における基本的な作業の 1 つに岩盤の 掘削および鉱石の積み込み・運搬がある。この基本的作業の 1 つ である積み込み作業では, 一般にホイールローダあるいはロード ホールダンプ (LHD) などの積み込み機械が使用される。ホイール ローダあるいはLHDによる自律作業を考えた場合，2．で詳述す るように，1）破砕堆積物の認識および作業計画の構築, 2) 移動経 路生成および自律走行, 3) 自律すくい取り作業, 4) ダンプトラッ クの認識, 5) 移動経路生成, 6) 自律積み込み作業などの一連の作 業を実現する必要がある。積み込み機械の走行に関しては, 既に 自動化の研究が数多く行われ，優れた成果が公表されている3 また移動経路生成 6)7), ダンプトラックの認識および自律積み込 み作業 ${ }^{8)}$ に関する研究例も見受けられる。しかしながら, これら 一連の作業の出発点ともいうべき破砕堆積物の形状認識に関し ては, あまり研究例がないのが現状である。すくい取り作業計画 では, 一般にバケットをどの位置からどの方向で破砕堆積物に貫 入させ，どのような軌跡でバケットを上昇させて土砂・鉱石をす くい取るかを決定することになるが，これは破砕堆積物の形状お

* 2000 年 4 月 13 日受付 6 月 13 日受理

1. 正会員 工博 東北大学助教授 大学院工学研究科地球工学専攻

2. 東北大学大学院生 工学研究科地球工学専攻博士前期課程

3. 正会員 工博 東北大学教授 大学院工学研究科地球工学専攻

[ 著者連絡先 ] FAX 022-217-7395 (東北大・地球)

キーワード: ビジョンシステム, 画像処理, 破砕堆積物
よび堆積量などを基に決定される。したがって, 破砕堆積物の形 状認識は必要不可欠な技術の 1 つであると考えられる。認識の手 法としては, 超音波やレーザを用いる方法などいくつかの方法が あるが, 画像は比較的広範囲の環境を瞬時に把握でき, さらに目 的に合った処理が容易にできるなどの利点を有しているため, 作 業ロボットの視覚として適しているといわれている910)。

それゆえ, 本研究では画像処理により破砕堆積物の形状を認識 するアルゴリズムについて検討することを目的とする。なお，本 研究では破砕堆積物の形状認識だけに焦点をあて, 堆積量の推定 は別途検討することにする。

\section{2. 自動化ホイールローダによる土砂・鉱石積み込み作業の概念}

図 1 は, 自動化ホイールローダによる土砂・鉱石積み込み作業 の概念を示したものである。以下，これについて詳述する。

(1) ホイールローダはビジョンシステムを有する。このビジョ ンシステムによりローダは, まず自分の掘削対象である破砕堆積 物が, どこに存在するかを認識する。破砕堆積物の存在が認識で きたならば, 次に破砕堆積物の形状を認識し, その形状を基に, バケットをどの地点からどの方向に貫入させるかといった作業 計画を構築する。

(2) ローダの初期位置・方向およびバケット貫入点の位置およ び貫入方向を基に, ローダの移動軌跡を生成する。さらに, 生成 された移動軌跡に沿って貫入点まで自律的に移動する。

(3) 貫入点までローダが到達した後, ローダはバケットを破砕 堆積物に貫入させ，土砂・鉱石をすくい取る。

(4) 土砂・鉱石をすくい取った後, ローダ上に装備されている ビジョンシステムは, 積み込み先であるダンプトラックまでの相 対距離および方向を認識する。

(5) ビジョンシステムが認識したダンプトラックまでの相対 距離および方向を基に, ダンプトラックまで接近する移動経路を 生成する。この移動経路は, その形状から, 一般に V ーシェープ と呼ばれている ${ }^{6)}$ 。さらにローダは, この経路に沿ってダンプト 


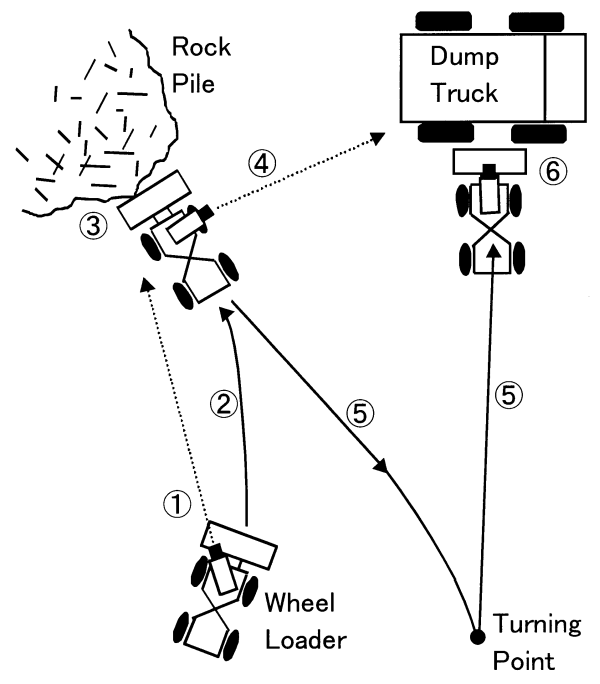

Fig. 1 Concept of autonomous scooping and loading operation.

ラックまで自律的に移動する。

(6) ローダがダンプトラックにある程度まで接近したならば, ローダはビジョンシステムによりダンプトラックのベッセルを認 識しながらさらにダンプトラックに接近する。その後, ローダは

最適な位置で停止し，土砂・鉱石をベッセルに積み込む。 本研究では，(1)における破砕堆積物の形状認識について検討す る。

\section{3. 破砕堆積物認識のための画像処理}

図 2 に本研究で提案する破砕堆積物認識のための画像処理のフ ローチャートを示す。

（1）サンプリング＼cjkstart初めに, CCD カメラにより作業現場の周 辺の画像をサンプリングする。

（2）平滑化 一般にサンプリングされた画像には雑音が含 まれているため, 前処理として雑音を取り除く処理を施す。この 雑音を取り除くためのフィルタとしては, 移動平均フィルタやメ ジアンフィルタなど，いくつかのフィルタが提案されている ${ }^{11}$ 。 一般に平滑化処理は，エッジをぼかしてしまう作用がある。しか し, 本研究では後述するようにエッジ情報を基に認識処理を行う ため, できるだけエッジをぼかさないフィルタを選択することが 望ましい。そこで, 本研究では比較的処理が簡単で, エッジをあ まりぼかさないメジアンフィルタを用いた。メジアンフィルタと は, 注目寸る画素とその 8 近傍の画素における画像強度值を昇順 に並べたとき, その中間の画像強度值を, 今注目している画素の 画像強度值と寸るフィルタである。

（3）エッジ検出物体の輪郭や特徵点を抽出することを目 的とした場合, 一般にエッジ検出処理が行われる。エッジ検出の ためのフィルタもソーベルフィルタやガウスラプラシアンフィル タなどいくつか提案されているが，本研究では計算が簡単なソー ベルフィルタを用いた。ソーベルフィルタを図 3 に示す。

（4） 2 值化 本研究で対象としている物体は，発破直後の破 砕堆積物であり, 最終的には破砕堆積物全体の形状を把握するこ とを目的とする。しかし，（3）の処理では，破砕堆積物以外の地 面・背景などのエッジも検出されてしまう。

ところで, 破砕堆積物は数多くの破砕された岩石で構成されて いるため, サンプリングされた画像中に破砕堆積物が存在する場 合, 破砕堆積物の領域におけるエッジ密度は, 他の領域のエッジ 密度と比較して大きくなることが予想される。そこで，後処理に

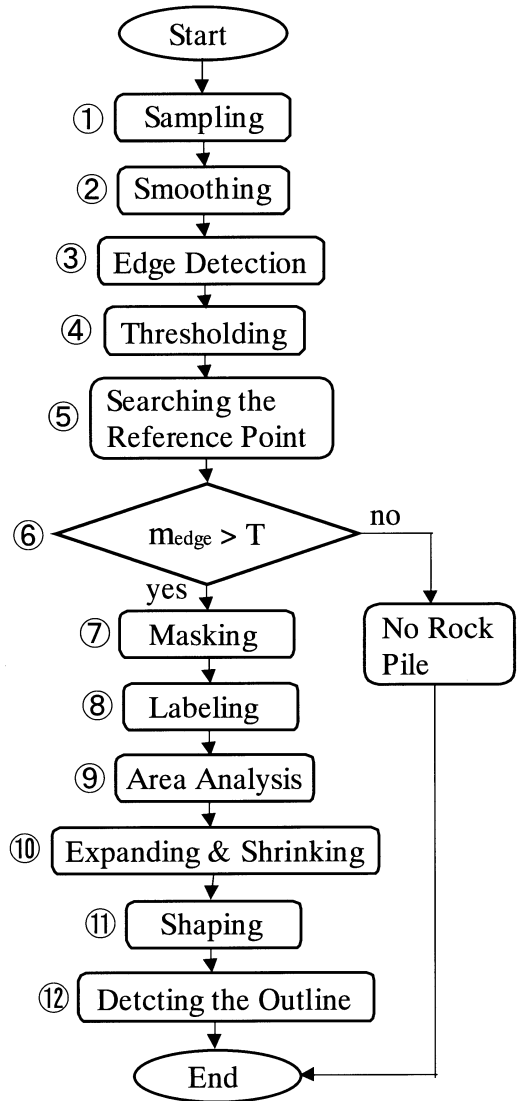

Fig. 2 Flowchart of image processing.
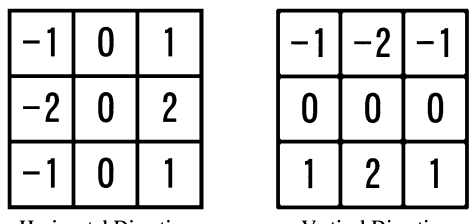

Fig. 3 Sobel filter.

おいてエッジ密度の計算を簡単にするために, 2 值化処理を施す。 2 值化処理を行う場合の最大の問題点は, しきい值をいくつに設 定するかであり, このしきい值の設定により, その後の処理結果 が大きく左右される。しきい值の決め方もいくつかの方法が提案 されてはいるが，ほとんどの場合，目的の後処理に合った最適な しきい值を試行錯誤により見出寸方法が一般に取られている。本 研究でも，試行錯誤によりしきい值を 100 に設定した。

（5）参照点の探索本研究では, サンプリングされた画像か ら破砕堆積物のみを抽出するために, 破砕堆積物領域内部に「あ る 1 点」を定め, ここを参照点と定義し, 「エッジ密度が高く, か つこの参照点近傍の領域と似た画像強度值を有寸る領域を残し, 他の領域を消去する」という処理で破砕堆積物領域のみを抽出す る方法を提案する。そこで, 破砕堆積物領域内に参照点を定めな ければならない。しかし，この参照点の決定に人手を介したので は，作業の自律化にはならない。そこで，本研究では以下のよう にして参照点を決定した。先に述べたように，破砕堆積物領域は， 他の領域に比べてエッジ密度が高いと考えられる。そこで, 後述 するように，本研究で用いた画像処理装置では，アナログ画像は $512 \times 440$ 画素のデジタル画像に変換されるので, 全体の $512 \times$ 440 画素領域を $16 \times 11$ 画素の 1,280 の領域に分割し, それぞれの 領域におけるエッジ密度を次式で定義した。 
$a=n / N$

ここに, $a$ はエッジ密度, $n$ は分割された各領域に含まれるエッ ジの数, $N$ は各領域の全画素数 $(=16 \times 11)$ である。エッジ密度が 高い領域は, 破砕堆積物領域内に含まれる確率が高いと考えられ ることから, エッジ密度の高い方から上位 50 個の分割領域を検出 し, これら 50 個の分割領域における座標を基にした重心を計算 し, その重心を参照点とする。

本研究で提案する方法では, この参照点は必ず破砕堆積物領域 内に含まれる必要がある。当然のことながら, 計算に用いた領域 の個数により重心の位置, すなわち参照点の位置は変化する。本 研究では, 撮影された多数の画像を解析し, 上位 50 個の分割領域 を基に重心を計算すれば，その重心はほとんど破砕堆積物領域内 に選定されることを確認したため上位 50 個と設定したが, この個 数については, さらに検討を要すると思われる。

なお，同様に分割領域の大きさによっても重心の位置は変化す る。本研究では, 分割領域の大きさを $8 \times 8$ 画素および $16 \times 22$ 画素とした場合についても検討を行ったが，16×11 画素とした 場合が最も良い結果を示したため, すなわち重心 (参照点) が破 砕堆積物領域内に入る確率が最も高くなったため, 本研究では分 割領域の大きさとして $16 \times 11$ 画素を採用した。

（6）破砕堆積物有無の判断 （1）〜（5）の処理は, サンプリン グされた画像中に破砕堆積物が存在するしないにかかわらず実行 される。画像中に破砕堆積物が存在しない場合, (5)の処理で選択 された上位 50 個の領域の平均エッジ密度は, 破砕堆積物が存在す る場合と比較してかなり小さくなることが予想される。そこで, 本研究では, 次の処理として選択された上位 50 個の領域の平均 エッジ密度を計算し, この值がしきい值よりも小さい場合には, 画像中に破砕堆積物は存在しないと判断し, 処理を中止する。こ のときのしきい值は，試行錯誤により 52 に決定した。

（7）マスク処理 画像中に破砕堆積物が存在すると判断さ れた画像に対しては, 次にマスク処理を施す。初めに, 図 4 に示 すように参照点を中心にした $8 \times 8$ 画素の参照領域を設定し, そ の参照領域内の平均画像強度值を計算する。平均画像強度值の計 算には，平滑処理後の原画像を用いる。

次に, 全画像領域を $8 \times 8$ 画素の 3,520 の領域に分割し, それ ぞれの分割領域に対して次式により2つのパラメータを計算する。

$$
\begin{aligned}
& B_{i j}=\frac{\left|B_{S t}-b_{i j}\right|}{\max \left(b_{i j}\right)-\min \left(b_{i j}\right)} \times 100 \\
& E_{i j}=\frac{\max \left(e_{i j}\right)-e_{i j}}{\max \left(e_{i j}\right)-\min \left(e_{i j}\right)} \times 100
\end{aligned}
$$

$b_{i j}:(i, j)$ 番目の領域における平均画像強度值

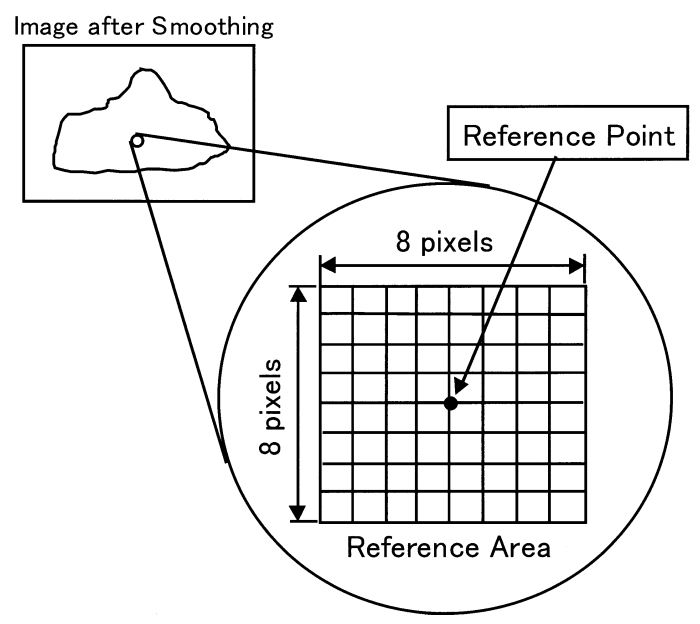

Fig. 4 Definition of reference area. $e_{i j}:(i, j)$ 番目の領域における平均エッジ密度

$B_{i j}:$ 正規化された $b_{i j}$ の值

$E_{i j}:$ 正規化された $e_{i j}$ の值

$B_{s t}:$ 参照領域における平均画像強度值

$\max \left(b_{i j}\right), \min \left(b_{i j}\right): b_{i j}$ の最大值および最小值

$\max \left(e_{i j}\right), \min \left(e_{i j}\right): e_{i j}$ の最大值および最小值

式 (2) から分かるように, 参照領域における画像強度值と分割領 域の画像強度值が近い場合, その分割領域における $B_{i j}$ の值は小さ くなる。すなわち, 参照領域は破砕堆積物領域内で選定されてい るため, $B_{i j}$ の小さな分割領域は破砕堆積物領域内に含まれる可能 性が高いことを示す。破砕堆積物領域内ではエッジ密度が高いと 考えられることから, 同様に $E_{i j}$ が小さくなる分割領域は破砕堆積 物領域内に含まれる可能性が高いと判断できる。それゆえ, $B_{i j}$ と $E_{i j}$ の両方がしきい值より小さい分割領域は, 破砕堆積物領域と判 断して残し，その領域の画素の值をすべて 255( 白 ) に変換する。 その他の領域は, 破砕堆積物領域以外と判断し, その領域の画素 の值をす心゙て 0 ( 黒) に変換する。

なお, 式 (2) では参照領域における平均画像強度值に近い分割 領域を探索することを目的としたものであるが，式 (3) は参照領 域における平均エッジ密度に近い平均エッジ密度を有する分割領 域を探索することを目的としたものではなく, エッジ密度の高い 分割領域ほど $E_{i j}$ が小さくなるようになっている。これは, 分割領 域内のエッジ密度が高ければ, 破砕堆積物領域内に含まれる確率 が高くなるため, 参照領域における平均エッジ密度に近い平均 エッジ密度を有する分割領域を探索するよりも, 式 (3) のように した方が，より確実に破砕堆積物を認識できたためである。なお， $B_{i j}$ と $E_{i j}$ に対するしきい值については後述する。

（8）ラベル処理 マスク処理後の画像は, 白黒の 2 值化画像 になっている。ここで白の領域に番号付けを行う。なお，この処 理は, 最終的な処理結果には全く影響を与えない。

（9）面積処理白を示寸領域のうち, 最大の白領域だけを残 し, 残りの領域は寸べて黒に変換して消去する。この処理は, 画 像中に含まれる破砕堆積物は 1 つのみで, 2 つ以上存在しないこ とを前提としている。ほとんどの現場では, この前提で問題ない が, 破砕堆積物が複数存在する現場では, このままでは対応でき ず変更が必要であるが, ここでは破砕堆積物が複数存在する状況 については考慮しないことにする。

（10）膨張および縮退処理 面積処理後の画像中には, 1 つの 大きな白領域が存在するが, その白領域の内部には, 数多くの黒 領域も存在している。そこで膨張および縮退処理を施す。本研究 で用いた画像処理装置では, 白の領域を基に処理を施すので, 黒 の領域を消去するためには, 膨張処理を行えばよい。各分割領域 の大きさは $8 \times 8$ 画素であるので, 初めに膨張処理を 4 回行えば, 白領域内の黒領域は消去される。その後, 白領域の元の大きさを 復元するために，同じ 4 回だけ縮退処理を施す。

（11）整形処理 （10）の処理により，破砕堆積物を示す大き な白い領域が検出されるが，この状態では領域の周囲に枝状の突 起のような領域が付随して残されていることが多い。そこで，こ の枝状の領域を消去し, 検出された領域が破砕堆積物の形状に近 い形状を示すように整形処理を施す。ここでは, 枝状の白い領域 を消去すればよいわけであるから，(10）とは逆に初めに縮退処理 を数回施し, その後, 元の大きさを復元するために同じ回数だけ 膨張処理を施せばよい。処理の回数は, 試行錯誤により4回と決 定した。

（12）輪郭抽出検出された領域の輪郭を抽出し, これを原 画像と重祆合わせて最終的な出力とし, 処理を終える。 


\section{4. 画像処理装置および画像サンプリング}

本研究に用いた画像処理装置は, (株) 日立製作所製画像処理ボー ド IP5000 である。このボードは Windows NT マシンの PCI スロッ トに装着し, ユーザー側で処理プログラムを組んで画像処理を実 行するようになっているが，付属の対話型ソフトを用いることに より, 基本的な画像処理の操作は実行できるようになっている。 本画像処理装置では, アナログ画像は $512 \times 512$ 画素 ( 有効画素 数 $512 \times 440)$ に標本化され, 各々の画素は光の強度に応じて 256 階調に量子化され, デジタル画像として保存される。サンプリン グにはデジタルカメラおよびデジタルビデオカメラを用いた。

破砕堆積物の画像をサンプリングした現場は, 東京石灰工業 (株) 仙台工場 (宮城県名取市) および丸森工場 (宮城県丸森町), 太平 洋セメント (株) 大船渡鉱山 (岩手県大船渡市), 八溝砕石 (株)( 福 島県棚倉町 ) の 4 箇所であり, 全部で 58 枚の画像をサンプリング した。東京石灰工業 (株) 仙台工場では, 比較的粒度の細かい砕石 が得られ, 一方, 丸森工場では節理の関係から粒度の大きい砕石 が得られることから, 粒度の違いの影響を調べるために, 両砕石 場にて画像をサンプリングした。太平洋セメント(株) 大船渡鉱山 では, 岩種・色彩の変化の影響を検討するため, 石灰岩の画像を サンプリングし, また八溝砕石 (株) では, 砕石の堆積物の画像を サンプリングするとともに, 再生骨材を生成するために積み上げ られているアスファルト堆積物の画像をサンプリングした。 (b) は平滑処理後の画像にエッジ検出を施した画像を示してい る。エッジ強度の強い部分は白く, またエッジ強度の弱い部分は 黒く表示されている。

(c) はエッジ検出後の画像を 2 值化した結果を示している。2 值 化を行う際のしきい值は, 上述したように試行錯誤により 100 と した。図を見ると破砕堆積物領域と思われる領域内ではエッジ密 度が高いことが分かるが, 背景にも多数のエッジが検出されてい る。

(d) は参照点の検出結果を示している。図中の四角の領域が先に 述べた「参照点の探索」処理においてエッジ密度の高い方から選 択された上位 50 個の分割領域を示しており, 図中の白丸が，これ ら 50 個の領域の位置座標を基に計算された重心位置, 寸なわち参 照点を示している。破砕堆積物に近い地面にもエッジ密度の高い 領域が多数検出されているため, 参照点が破砕堆積物のやや下方 で検出されているが，破砕堆積物領域内に入っていることが分か る。

(e) はマスク処理後の結果を示している。本研究では, エッジ密 度が高く, かつ破砕堆積物領域内に設定される参照領域の平均画 像強度值に近い平均画像強度值を有する領域を残寸方法を採用し ているため, 破砕堆積物領域内では多くの白領域が見られるが, まだこの状態では背景にも数多くの白領域が存在していることが 分かる。

（f）は面積処理後の結果を示している。（e）の画像中における全

\section{5. 破砕堆積物認識結果}

\section{$5 \cdot 1$ 破砕堆積物存在の有無判断}

撮影された全 58 枚の画像について検討した結果, 上述したようにエッジ密度の高い方から上位 50 個の 分割領域における平均エッジ密度に対するしきい值 を 52 とすると，94\%の判断成功率を示すことが確 かめられた。誤判断は, 寸べて破砕堆積物が存在す る画像に対して,「破砕堆積物は存在しない」と判断 したもので，その逆の誤判断は無かった。誤判断が 生じた 3 枚の画像は，いずれも破砕堆積物から遠く 離れた位置で画像のサンプリングを行ったものであ り, その結果, 原画像に十分なコントラストが得ら れず，エッジ強度が小さくなったために「存在しな い」と判断されたと考えられる。したがって, サン プリング位置, 寸なわち作業ロボットの位置が破砕 堆積物から，かなり離れていると判断されるような 場合は，破砕堆積物に近づいてからサンプリングを 再び実行するなどの処理が必要になると思われる。 本研究では, この判断アルゴリズムについては検討 しておらず今後の課題であるが，本研究で提案する 破砕堆積物存在の有無判断アルゴリズムは高い成功 率を示し，また上述したような自己位置をさらに破 砕堆積物に近づけるといった処理が可能になれば, ほぼ $100 \%$ の判断が可能になると考えられる。

\section{$5 \cdot 2$ 破砕堆積物の形状認識}

図 5 に画像処理結果の一例を示した。

(a) は東京石灰工業(株) 仙台工場で撮影された原画 像を示している。これは, 発破直後の砕石の堆積物 を示しており，切羽の前に破砕堆積物が存在してい る。この画像に平滑処理を施すが，見た目ではほと んど変化の様子が分からないので, 平滑処理後の画 像は紙面の関係上, 割愛する。

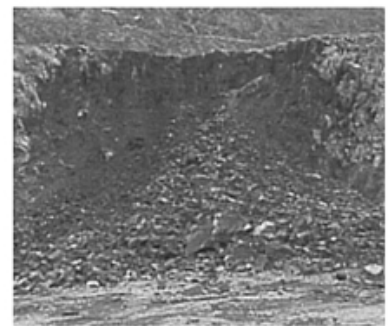

(a)

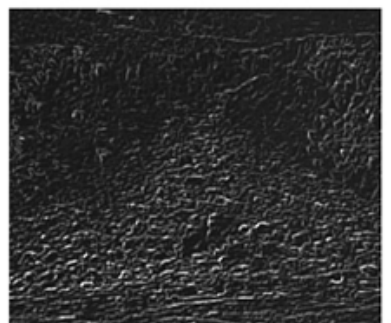

(b)
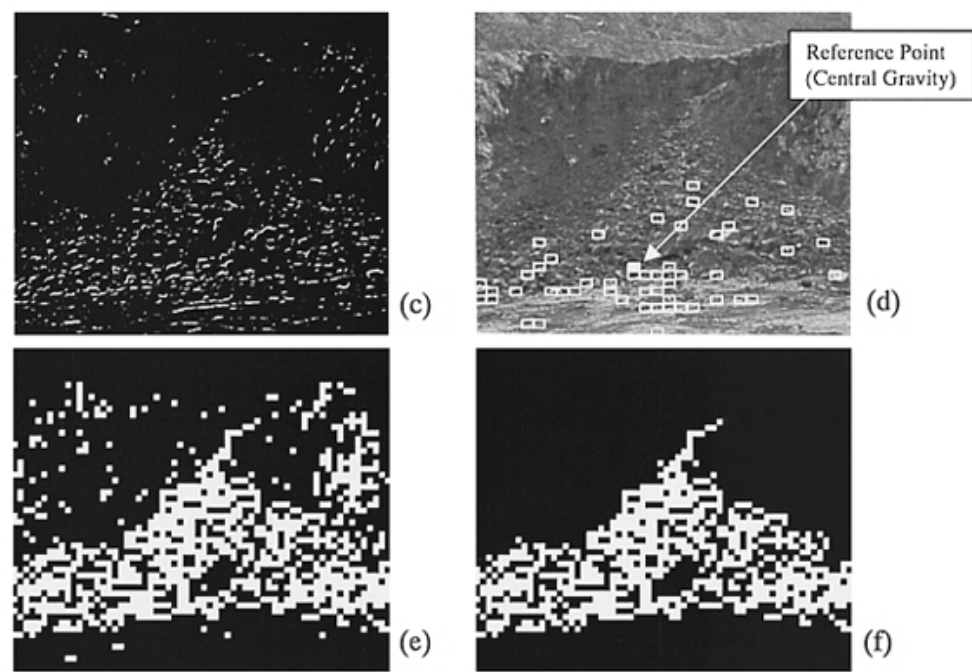

(c)

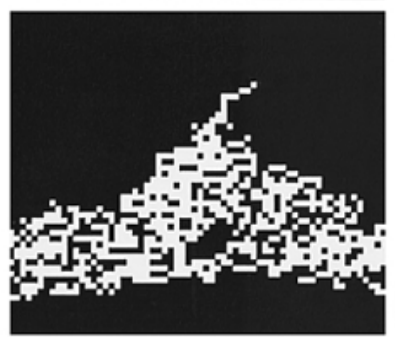

(f)
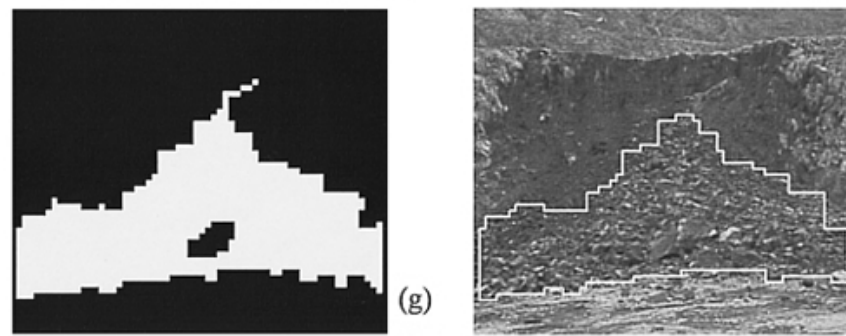

(h)

Fig. 5 An example of the results in each process 
ての白領域の面積を計算し，最大の領域だけを残し，他の領域は 消去してある。なお, 本研究では, 図 6 に示すように分割した領 域が点で接している状態 (図中の○印) も, 白領域が連続してい ると見なしている。この状態では, 堆積物のおおよその輪郭が得 られているが, 内部には数多くの黒領域が存在していることが分 かる。

(g) は膨張および縮退処理を施した結果を示している。白領域内 に存在していた数多くの黒領域が消去されていることが分かる。 (g) には白領域内に若干大きいの黒領域が 1 残っていることが分 かる。これは, 破砕堆積物表面に存在していた大岩領域に相当す る。すなわち, 本画像処理アルゴリズムでは, 破砕堆積物表面に 存在する大岩の検出も可能である。大岩の存在は作業全体の効率 に影響を与えるので, 大岩存在の有無判断は作業の効率化のため に有効な手法である。しかし，作業に影響を与えるような大岩で あるかどうかということは, ローダのバケット寸法やダンプト ラックのベッセルの大きさなどと対比して定量的に処理すべきで あり, この定量評価には, 大岩の実寸法を計測することが必要に なる。この計測を画像を用いて行おうとすると，ローダと破砕堆 積物との間の距離などの影響を受けるため複雑であり，今後の検 討課題であると考える。

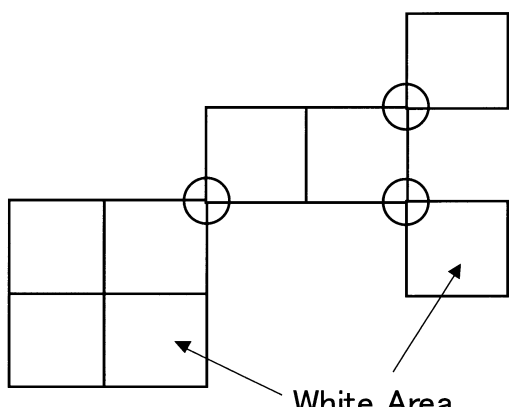

Fig. 6 Definition of the connecting point.
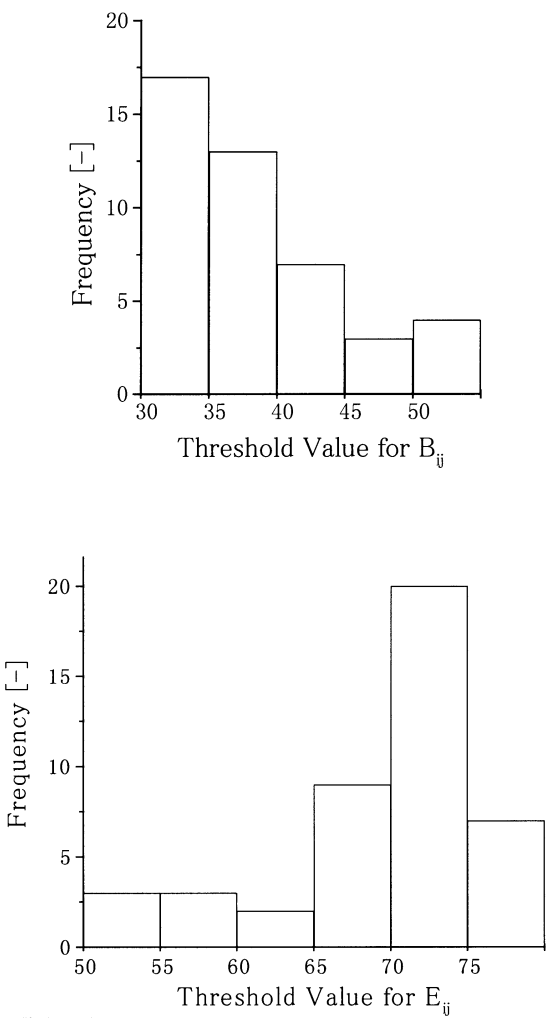

Fig. 7 Frequency distribution of threshold value for $B_{i j}$ and $E_{i j}$. （h）は整形処理を施し, (g) の状態で検出領域の上部に存在して いた枝状の突起を消去し, さらに検出された領域の輪郭を抽出し て, 比較のため原画像に重社合わせた結果を示している。この図 に示されるように, 抽出された破砕堆積物の輪郭は, 実際の破砕 堆積物の輪郭とほぼ一致していることが分かる。

ところで， $B_{i j}$ および $E_{i j}$ に対するしきい值であるが，式 (2) およ び（3）に示すように正規化を行ったものの，本研究ではすべての 画像に対して一定のしきい值を設定することができなかった。こ れは，同一の破砕堆積物を対象としても，撮影する位置が異なれ ば，画像強度值およびエッジ強度ともに異なり，この影響を式 (2) および (3) のみでは十分にキャンセルできなかったためと考えら れる。したがって, 画像ごとに $B_{i j}$ および $E_{i j}$ に対するしきい值を 設定した。図 7 に認識がほぼうまくいった画像に対する最適なし きい值の頻度分布を示した。B $B_{i j}$ に対しては, 最適なしきい值はほ ぼ 30 〜 55 の範囲内の值となったが, $30 \sim 40$ の頻度が高くなっ ている。また $E_{i j}$ に対しては, 最適なしきい值はほぼ $50 \sim 80$ の範 囲内の值となったが, $65 \sim 75$ の頻度が高くなっている。今後, こ れらのしきい值を破砕堆積物から作業ロボットまでの距離などの 関数で表すように検討を進めていきたい。

図 8 は, 他の現場でサンプリングされた画像を処理した結果の 一例を示している。現場は，(a) 太平洋セメント(株) 大船渡鉱山，
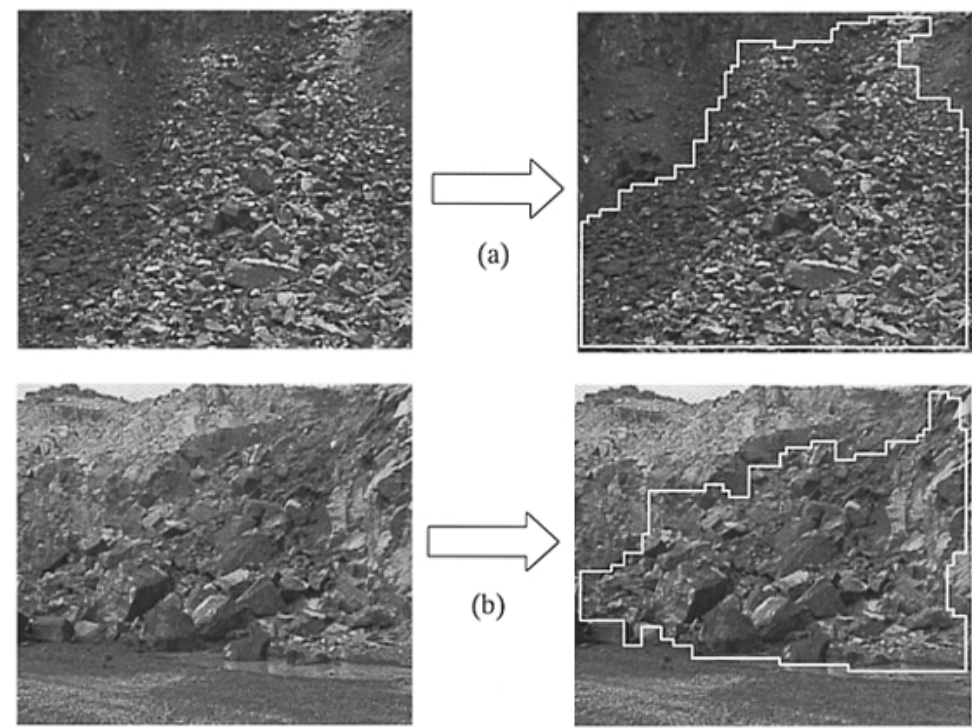

(b)
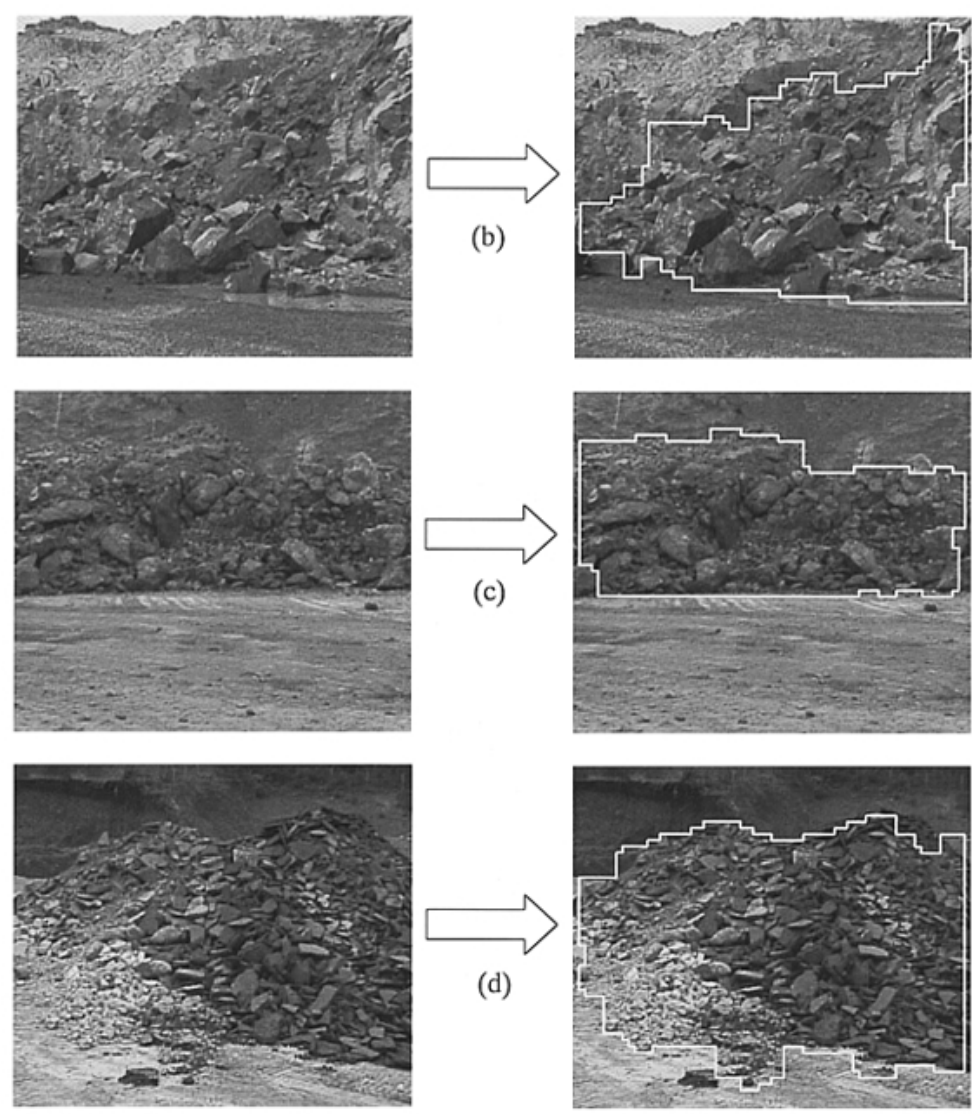

Fig. 8 Some examples of the shape detection of other rock piles. 
（b)，(c) 東京石灰工業 (株) 丸森工場，(d) 八溝砕石 (株)である。砕 石と比較して若干白色の強い石灰石でも破砕堆積物をうまく検出 しており, また本画像処理アルゴリズムは (b)および (c) に示すよ うに, 粒度の大きい砕石による堆積物にも適用できることが分か る。また（d）はアスファルトの堆積物に対して本画像処理アルゴ リズムを適用した結果であるが，色彩の黒いアスファルトに対し ても堆積物の形状を適切に抽出していることが分かる。 $B_{i j}$ および $E_{i j}$ に対寸るしきい值に検討の余地が残されているものの, 以上の ように, 本研究で提案する本画像処理アルゴリズムは, 破砕堆積 物形状認識の手法として有効であると考えられる。

なお，既に何回か述べているように，本研究では，エッジ密度 が高く, かつ破砕堆積物領域内に設定される参照領域の平均画像 強度值に近い平均画像強度值を有する領域を残寸方法を採用して いるため, エッジができるだけ数多く検出されることが望ましい。 したがって, 例えば丸森工場のように比較的大きな岩石塊による 堆積物の場合, 画像の大半に堆積物が写ってしまうような近距離 で画像のサンプリングを行うと, エッジの個数が少なくなり，ほ とんどの場合, 堆積物の形状検出がうまくいかなかった。このよ うな場合は, 破砕堆積物から離れてもう 1 度サンプリングを行う などの処理が必要になってくると思われるが，画像からその判断 を行うアルゴリズムについては今度の課題である。また本処理で は, 画像をサンプリングしてから最終的な結果を出力するまでに 約 30 秒を有した。処理の部分を回路化するなどの方法を採用すれ ば，さらに処理時間を削減することができると思われるが，検出 の精度を高め, さらに処理時間を短縮するように処理アルゴリズ ムを工夫することも必要である。

ところで, 積み込み作業において, 破砕堆積物の形状は作業の 進行とともに常に変化するため, ローダは 1 回の積み込み作業ご とに破砕堆積物の形状を認識することが望ましい。そのためには, 認識に要する時間をできるだけ短くする必要があるが, 本研究で 提案するアルゴリズムでの処理時間は約 30 秒程度であるため, こ の程度の処理時間であれば, 毎回の作業ごとに破砕堆積物の形状 を認識することが可能であると考えられる。

なお，2. (1)で述べたように，ホイールローダの自律作業を実現 するためには, この次のステップとして, 画像処理により認識さ れた破砕堆積物の形状を基に, すくい取りの作業計画を構築する 必要がある。今後はこの作業計画の構築に取り組む予定であるが, ここでこの作業計画について少し述べる。

作業計画では, どの地点およびどの方向から積み込み作業を実 行するかを決定する必要がある。熟練オペレータは, 破砕堆積物 を見てその形状および堆積量を瞬時に認識し, 最適な積み込み地 点および方向を決定して積み込夕作業を実行する。したがって, コンピュータを用いて熟練オペレータの作業を実現するために は，以下の技術を開発する必要がある。

・本研究で実現した破砕堆積物の形状認識の結果を基に 3 次元
計測の範囲を特定し, さらに 3 次元計測を実行して, 破砕堆 積物の 3 次元形状および堆積量を認識する。

・堆積量および 3 次元形状を基に, 最適な作業計画 ( 積み込み 地点および方向）を構築する。この作業計画の構築には, 熟 練オペレータが, 判断基準や形状認識をどのように作業計画 に反映しているかをヒアリングするとともに，その結果を人 工知能などを用いて実現することが重要である。さらに，そ の実現に際しては，どの地点および方向が最適になるかを判 断する必要があり, その判断のために適切な評価関数を導入 する必要があると考えられる。

\section{6. むす び}

本研究では, 画像処理を用いて破砕堆積物の形状を認識するア ルゴリズムについて検討した。ここで提案するアルゴリズムは, エッジ密度が高く, かつ破砕堆積物領域内に選択される参照領域 の画像強度值に近い平均画像強度值を有する領域を残寸という手 法を基にしている。4 箇所の現場で破砕堆積物の画像をサンプリ ングした結果，本アルゴリズムは，破砕堆積物形状認識の手法と して有効であることが確かめられた。しかし，本アルゴリズムで はエッジ情報が重要な役割を果たすが，大岩からなる堆積物を近 くからサンプリングした画像では, 検出されるエッジ個数が小さ くなり, また破砕堆積物から遠く離れてサンプリングした画像で は, 原画像のコントラストが低く, その結果, エッジ強度が小さ くなった。このような画像に対しては, 破砕堆積物存在の有無判 断で誤判断を示す確率が高くなるばかりでなく, 正しい判断を示 した画像に対しても, その後の破砕堆積物形状認識がうまくいか ないことが多かった。認識に関しては，マスク処理がうまくいく かどうかという点によるところが大きいが，このようなエッジ強 度の小さい画像に対する処理は, 今後さらに検討したいと考えて いる。

最後に, 破砕堆積物の画像の撮影に際してお世話になった太平 洋セメント(株) 大船渡鉱業所, 東京石灰工業(株) 仙台工場および 丸森工場ならびに八溝砕石 (株) の関係各位にお礼申し上げる。

\section{引用 文 献}

1）山本欣市，柿倉 正義編著：極限作業ロボット，p. 217 - 341 (1992)，工業調查会

2) Petty, M.K. et al. : Proc. of the 4th Annual Conf. on Mechatronics and Machine Vision in Practice, p. 219 - 224 (1997)

3) At-Amant, M. et al. :Proc. of the 1st Int. Symposium on Mine Mechanization and Automation, Vol. 1, p. $6.1-6.10$ (1991)

4) Herteau, R. et al. : Proc. of the 1st Int. Symposium on Mine Mechanization and Automation, Vol. 1, p. $6.11-6.20$ (1991)

5) Gocho, T. et al. : Proc. of the 9th Int. Symposium on Automation and Robotics in Construction, Vol. 2, p. $803-812$ (1992)

6）皿田 滋，坪内孝司，油田信一：資源と素材，Vol. 112，p. 531-536(1996)

7) 小西泰史 : 東北大学修士学位論文 (1999)

8) 高橋 弘, 沖田 謙: 土木学会論文集, No. 581 / VI-37, p. $145-154$ (1997)

9) 木内雄二：画像認識のはなし, p. 1 (1993), 日刊工業新聞社

10) 鎌田博之: 東北大学修士学位論文 (1995)

11）画像処理ハンドブック編集委員会編 : 画像処理ハンドブック, p. 58 - 61 (1987), 昭晃堂 